\title{
INDEX PENULIS
}

Jurnal Pengembangan Kota Volume 3 Nomor 1 Tahun 2015

Amelia, Puteri Rizqi 26

Firdaus, Lutfi Rahmat 1

Manaf, Asnawi 40

Mussadun 26

Rahdriawan, Mardwi 11

Ratnasari, Dwi Jayanti 40

Putra, Andhi Pratama 60

Sariffuddin 49

Sestiyani, Efri 49

Yuliani, Yani 11

Yuliastuti, Nany 1 


\section{INDEX SUBYEK}

Jurnal Pengembangan Kota Volume 3 Nomor 1 Tahun 2015

Air bersih 11

Composite Index 60

Berbasis masyarakat 11

Dokumen Rencana 26

Evaluasi 26

GIS 60

Keberhasilan program 40

Kesesuaian Lahan 26

Kinerja pelayanan 11

Pengaruh 1

Perubahan Penggunaan Lahan 49

Perubahan Perumahan 49

Perubahan Sarana Prasarana dan Utilitas Umum 49

Program PLPBK 40

Rukun Tetangga 1

Rumah Susun Dinas 1

Tsunami 60

Vulnerability 60 


\section{Jurnal Pengembangan Kota \\ Volume 3 | Nomor 1 | Juli 2015 | Halaman 1-79 \\ ISSN: 2337-7062 (print)}

\section{INFORMASI PENERBITAN}

Naskah manuskrip harus dikirimkan melalui salah satu cara berikut ini:

1. Pengiriman naskah manuskrip sebaikmya dengan Online Submission System di portal E-Journal Pengembangan Kota (http://ejournal2.undip.ac.id/index.php/ipk)

2. Pertama Penulis mendaftarkan sebagai Penulis dan/atau Reviewer (mencentang role sebagai Author dan/atau Reviewer) di bagian "Register" atau alamat: http://ejournal2.undip.ac.id/index.php/jpk/login

3. Setelah Penulis login sebagai Author, klik di "New Submission". Tahapan submit artikel terdiri dari 5 tahapan, yaitu: (1). Start, (2). Upload Submission, (3). Enter Metadata, (4). Upload Supplementary Files, (5). Confirmation 4. Di bagian Start, pilih Jurnal Section (Full Article), centang semua ceklist.

4. Di bagian Upload Submission, silakan unggah file manuskrip artikel dalam MS Word di bagian ini.

5. Di bagian Enter Metadata, masukkan data-data semua Penulis dan afiliasinya, diikuti dengan judul dan abstrak, dan indexing keywords.

6. Di bagian Upload Supplementary Files, diperbolehkan mengunggah file data-data pendukung atau surat pengantar atau dokumen lainnya.

7. Di bagian Confirmation, silakan klik "Finish Submission" jika semua data sudah benar.

8. Jika penulis kesulitan dalam proses pengiriman naskah melalui sistem daring, naskah manuskrip dapat juga dikirimkan melalui E-mail ke email Editorial Jurnal Pengembangan Kota (ipk.labkota@live.undip.ac.id) 
